\title{
Performance of a direct steam generation solar thermal power plant for electricity production as a function of the solar multiple
}

\author{
M.J. Montes , A. Abánades, J.M. Martínez-Val \\ E.T.S.I.Industriales - U.P.M. ClJosé Gutiérrez Abascal, 2. 28006 Madrid, Spain
}

\begin{abstract}
This paper describes the influence of the solar multiple on the annual performance of parabolic trough solar thermal power plants with direct steam generation (DSG). The reference system selected is a $50 \mathrm{MW}_{\mathrm{e}}$ DSG power plant, with thermal storage and auxiliary natural gas-fired boiler. It is considered that both systems are necessary for an optimum coupling to the electricity grid. Although thermal storage is an opening issue for DSG technology, it gives an additional degree of freedom for plant performance optimization. Fossil hybridization is also a key element if a reliable electricity production must be guaranteed for a defined time span. Once the yearly parameters of the solar power plant are calculated, the economic analysis is performed, assessing the effect of the solar multiple in the levelized cost of electricity, as well as in the annual natural gas consumption.
\end{abstract}

Keywords: Direct steam generation; Parabolic trough collector; Solar thermal power plant; Solar multiple; Hybridization

\section{Introduction}

Current parabolic trough solar thermal power plants connected to the electricity grid are based on oil as heat transfer fluid in the collectors. The main disadvantage of this technology is the maximum power block inlet temperature, which is limited to the oil upper working temperature in order to guarantee this fluid thermal stability. Although there are some alternatives, like the use of molten salts in the parabolic trough collector, none of them have been scaled to a commercial size. Besides that, all these options, called heat transfer fluid (HTF) technologies, require a heatrecovery steam generator (HRSG) between the solar field and the power block, which introduces additional heat losses and pressure drops in the global efficiency.
Direct steam generation is considered a very promising option to increase the efficiency of parabolic trough systems, not only because there is no need of a heat exchanger between the solar field and the power block (Montes et al., 2008), but also owing to the higher temperatures that can be attained in the collector receivers. This last reason is especially important at present, when new commercial absorber tubes, for working at higher temperatures, have been developed (Benz et al., 2008).

At present, there are two projects to develop pre-commercial demonstration plants based on DSG technology, they all to be implemented in the southern of Spain. Net electrical power of these plants will be $3 \mathrm{MWe}$ (Zarza et al., 2008) and $5 \mathrm{MWe}$ (Eck et al., 2008), respectively. The analysis presented in this paper is referred to a $50 \mathrm{MWe}$ net DSG power plant. It has been selected this power because it is a relevant size for commercial projects.

Solar multiple has been chosen as the design parameter for the sensitivity analysis of annual plant performance and economic assessment. Annual performance is based on the 
daily operation of the plant during type-days chosen from every month of the year. Yearly electricity production is the same for all the configurations considered, because a scheduled load operation strategy has been adopted. Parabolic trough solar thermal plants can operate in this mode if fossil back-up and storage system are used. Once the annual performance parameters has been obtained, the levelized cost of electricity can be calculated, as a function of the solar multiple, because this parameter determines the collector field area and, as a consequence, the thermal storage size and the annual fuel consumption.

\section{DSG solar power plant design}

\subsection{Solar field}

According to the nominal power of the plant, an 'I' shaped layout for the solar field has been adopted (Kelly and Kearney, 2006). In this configuration, the solar field is divided into two header-pair sections, with the power block placed at the centre of the field. A cold header pipe runs from the power block through the centre of each section. Cold fluid is distributed from the cold header pipe to the collector loops of each side of the pipe, going through a series of collectors arranged in a row, reversing direction, and then coming back to the hot header pipe through the remaining collectors. Fig. 1 shows the configuration explained in this paragraph.

As it will be said in next sections, the solar field size basically depends on the solar multiple adopted for the power plant. Besides that, solar field arrangement must keep the following symmetry criterion: the number of collector loops must be always a multiple of four, in order to have a well-balanced pressure map in the field. For example, for a solar multiple equal to $1(\mathrm{SM}=1)$, the number of collector loops is 36 whereas if the solar multiple is 2 $(\mathrm{SM}=2)$, the number of collector loops is 76 . The solar

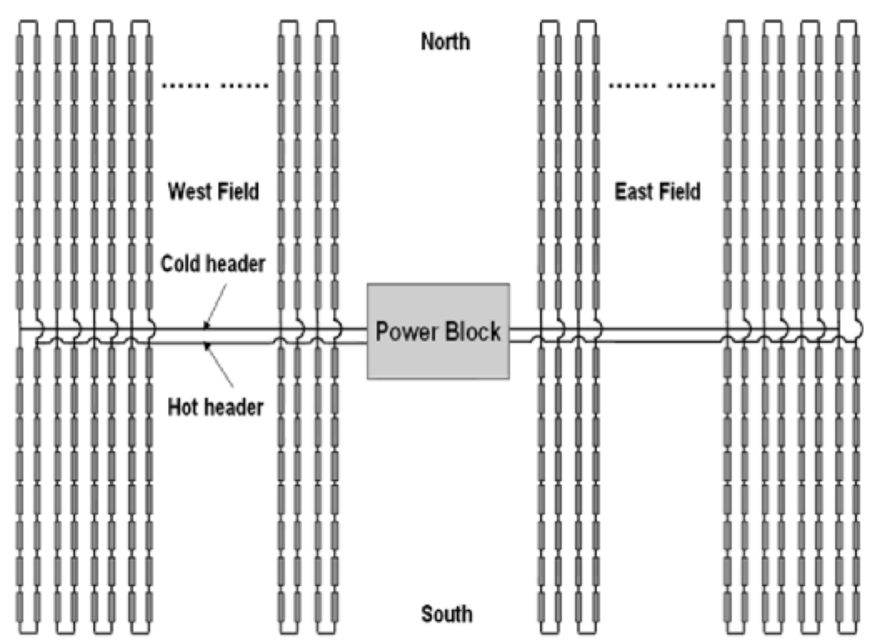

Fig. 1. Collector field layout considered for the DSG solar power plant. multiple determines the pressure drop and heat loss in header pipes, since both parameters depend on the solar field size and connections length. For a collector loop, outlet superheating steam temperature and pressure will be higher as the solar multiple increases because losses in header pipes increase and the power block inlet conditions remain constant.

The study presented in this paragraph has been focused on the thermal performance of a typical loop, referred to the case of solar multiple equal to $1(\mathrm{SM}=1)$ and nominal conditions. When using water/steam, the optimum mass flow per loop should be in the range of $1-2 \mathrm{~kg} / \mathrm{s}$, in order to have reasonable values of pressure drop in every loop (Zarza et al., 2006). In this case, the superheated steam produced at every loop is $1.459 \mathrm{~kg} / \mathrm{s}$. The recirculation operating mode has been adopted, so there is a water/steam separator between the end of the boiling section and the inlet of the superheating steam section. The recirculation rate, defined as the ratio of mass flow in the recirculation line and the steam mass flow, has been set to 0.3 at design-point conditions. This value of recirculation rate is equivalent to a steam quality of 0.77 . Preheating and boiling section are long enough to evaporate feed water mass flow $(1.897 \mathrm{~kg} / \mathrm{s}$ at nominal conditions), from inlet conditions to saturated steam with the quality previously set. In the same way, the length of the superheated section will be the necessary to supply steam at $500{ }^{\circ} \mathrm{C}$ and 90 bar at the turbine inlet. In order to account pressure drop and heat loss at the piping system, the steam pressure and temperature at the loop outlet will be higher than those required at the turbine inlet; for a solar multiple of one, these steam thermal conditions are 96 bar and $515^{\circ} \mathrm{C}$. Water/steam properties along the loop depend on the solar multiple adopted in each case. Nevertheless, collector loop configuration is the same for all the solar multiples considered, as it can be seen in Table 1 .

The power block and the solar multiple determines the steam mass flow that must be supplied by the solar field at nominal conditions, as well as the thermal properties of the feed water and the steam at the inlet/outlet of the solar field. For this specific case, total steam mass flow required is $52.53 \mathrm{~kg} / \mathrm{s}$, at $500^{\circ} \mathrm{C}$ and 90 bar. This mass flow is divided into 36 loops (for $\mathrm{SM}=1$ ), so the steam produced in very row is $1.459 \mathrm{~kg} / \mathrm{s}$. Thermal conditions of the water at the inlet of the solar field are $245^{\circ} \mathrm{C}$ and 107 bar.

Optical and geometrical parameters used in the performance model are those corresponding to the ET-100 parabolic trough collector. Optical properties for the selective coating were carefully determined (Zarza, 2007). These values are shown in Table 2. At this point, it is important to say that optimized absorber tubes, for working at $525^{\circ} \mathrm{C}$, have been considered. It is also expected that optical behaviour of the selective coating will be improved in the future, with lower emissivity values at higher temperatures, so thermal efficiencies will be still better that ones presented in this work. 
Table 1

Solar field configuration for a 50 MWe DSG power plant as a function of the solar multiple.

\begin{tabular}{|c|c|c|}
\hline \multicolumn{3}{|l|}{ Solar Field } \\
\hline Collectors Orientation & \multicolumn{2}{|c|}{$\mathrm{N}-\mathrm{S}$} \\
\hline Parabolic trough collector design & \multicolumn{2}{|c|}{ EuroTrough ET-100 } \\
\hline \multirow{11}{*}{ Number of collector loops } & $S M=1$ & 36 \\
\hline & $\mathrm{SM}=1.1$ & 40 \\
\hline & $\mathrm{SM}=1.2$ & 44 \\
\hline & $\mathrm{SM}=1.3$ & 48 \\
\hline & $\mathrm{SM}=1.4$ & 52 \\
\hline & $\mathrm{SM}=1.5$ & 56 \\
\hline & $\mathrm{SM}=1.6$ & 60 \\
\hline & $\mathrm{SM}=1.7$ & 64 \\
\hline & $S M=1.8$ & 68 \\
\hline & $S M=1.9$ & 72 \\
\hline & $S M=2$ & 76 \\
\hline \multicolumn{3}{|c|}{ Configuration of one loop (Valid for all the solar multiples considered) } \\
\hline $\begin{array}{l}\text { Number of collectors in series per } \\
\text { loop }\end{array}$ & \multicolumn{2}{|c|}{$\begin{array}{l}10 \text { collectors in total: } \\
>\text { Preheating + boiling section: } 7 \text { collectors } \\
>\text { Superheating section: } 3 \text { collectors }\end{array}$} \\
\hline $\begin{array}{l}\text { Number of modules }{ }^{*} \text { per collector } \\
\left({ }^{*} \text { Length of every module: } 12.27 \mathrm{~m}\right)\end{array}$ & \multicolumn{2}{|c|}{$\begin{array}{l}\text { Preheating + boiling section }(687.12 \mathrm{~m}) \text { : } \\
8 \text { modules per collector } \\
\\
\text { Superheating section }(306.75 \mathrm{~m}) \text { : } \\
\text { - Collector 1: } 9 \text { modules per collector } \\
\text { - Collectors 2-3: } 8 \text { modules per collector }\end{array}$} \\
\hline
\end{tabular}

Table 2

Absorber tube optical parameters for the ET-100 parabolic trough collector

\begin{tabular}{ll}
\hline Optical parameters of the ET-100 collector & \\
Intercept factor & 0.92 \\
Mirror reflectivity & 0.92 \\
Glass transmisivity & 0.945 \\
Solar absortivity & 0.94 \\
Peak optical efficiency & 0.75 \\
Thermal emissivity & $0.04795+0.0002331^{*} T\left({ }^{\circ} \mathrm{C}\right)$ \\
\hline
\end{tabular}

The solar field design-point adopted is solar noon on June 21st. Location coordinates are $37^{\circ} 03^{\prime} \mathrm{N}$ and $2^{\circ} 23^{\prime}$ W (Almería, Spain). For this site, at this time, direct solar irradiance is $900 \mathrm{~W} / \mathrm{m}^{2}$, air temperature is $25^{\circ} \mathrm{C}$ and incidence angle of solar radiation is $13.41^{\circ}$.

\subsection{Power block}

The power block considered is a regenerative $50 \mathrm{MWe}$ Rankine cycle. According to the size of the cycle, it is advis- able to have four extraction points from the steam turbine, that is, the feed water will be preheated in two low pressure closed feed water heaters, a degasifier, and a high pressure closed feed water heater. The extraction points are arranged so that the enthalpy of feed water increases in each water heater roughly by the same magnitude (Kostyuk and Frolov, 1988). Common parameters for the power block considered are showed in Table 3 .

It has been said in the introduction that one of the main features of the DSG technology is the actual possibility of increasing the superheated steam temperature up to $500{ }^{\circ} \mathrm{C}$, or even more in the future. This higher operation temperature results in two advantages for the power block. The main advantage is higher efficiencies as turbine inlet temperature increases. Another interesting consequence is the possibility of omitting a non-necessary steam reheating, which would not mean an efficiency increase. Steam reheating would be only necessary at lower turbine inlet temperatures, in order to avoid a great wetness fraction of steam at the turbine exhaust, which means a penalty in the turbine life-time, owing to the erosion of last steam turbine blades by water droplets. Besides that, the steam reheating 
Table 3

Design-point parameters for the 50 MWe Rankine power cycle.

\section{Turbine}

Isentropic efficiency

Electro-mechanical efficiency

0.9

0.98

Condenser pump

Isentropic efficiency

Electro-mechanical efficiency

Injection pump

Isentropic efficiency

Electro-mechanical efficiency

Low pressure closed feedwater heater

Terminal temperature difference $\left({ }^{\circ} \mathrm{C}\right)$

Drain Cooling Approach $\left({ }^{\circ} \mathrm{C}\right)$

Pressure loss in the tube side (bar)

Pressure loss in the shell side (bar)

High pressure surface type heater

Terminal temperature difference $\left({ }^{\circ} \mathrm{C}\right)$

Drain cooling approach $\left({ }^{\circ} \mathrm{C}\right)$

Pressure loss in the tube side (bar)

Pressure loss in the shell side (bar)

Condenser

Condenser pressure (bar)

integration would carry on several technological complications for this particular case; it is clear that the option of reheating directly in the solar field implies a complex configuration with high steam pressure drop; the alternative of using an auxiliary fired boiler means an additional natural gas consumption.

Wet cooling is assumed in the condensate system. For the reason, the condensation pressure is extremely low, 0.07 bar, favourable value to increase the power cycle efficiency. Figs. 2 and 3 shows a simplified scheme and the Mollier diagram for the Rankine cycle considered.

\subsection{Support systems for the solar field-power block-} electricity grid coupling: Thermal storage and auxiliary fired boiler

In order to guarantee steady conditions at the power cycle inlet and solar power plant output management, two key systems has been considered in the DSG based plant, a thermal storage and a natural gas-fired boiler.

For oil based plants, the most suitable storage system is an indirect two-tank, molten salt system (Price et al., 2002), with an oil/molten salt heat exchanger between the collectors field and the thermal storage. In case of using water/ steam as heat transfer fluid in the solar field, this option does not fit, owing to the pinch point generated between streams in the heat exchanger.

It has been demonstrated that one effective option for the storage system consists of three storage sections for preheating, evaporation and superheating. For water preheating and steam superheating ranges, sensible heat storage is the best option while latent heat storage is advantageous for evaporation section (Birnbaum et al., 2008). A thermal storage for direct steam generation technology, with two storage modules - a phase change material module for the evaporation section, and a concrete module for the superheating section -, is being demonstrated, at the southern of Spain, within the ITES project (Eck et al., 2008). Nevertheless, for the analysis presented in this work, it has been only considered the thermal behaviour of a theoretical thermal storage system, with a charging/discharge utilization factors and a global efficiency of 0.95 (Winter et al., 1990).

For a proper coupling between the solar field and the power block, and the power block with the electricity grid, it is necessary an auxiliary fossil-fired boiler, besides the thermal storage. There are several reasons to take into account both systems and not only one of them. If only

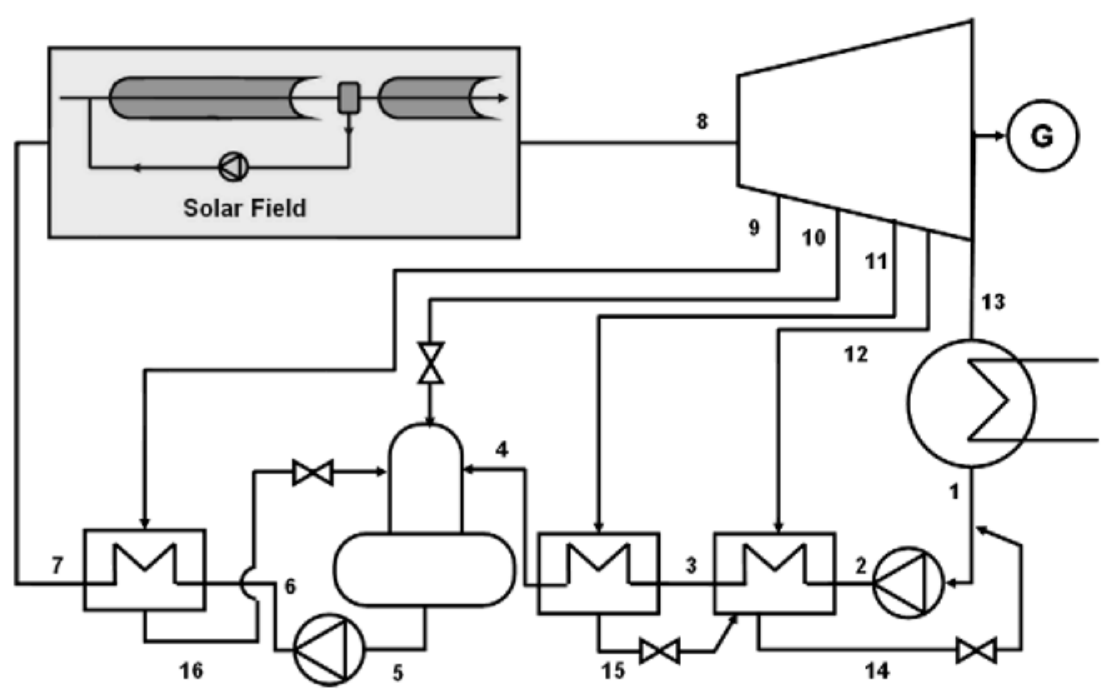

Fig. 2. Simplified scheme of the power block for the 50 MWe DSG solar power plant. 


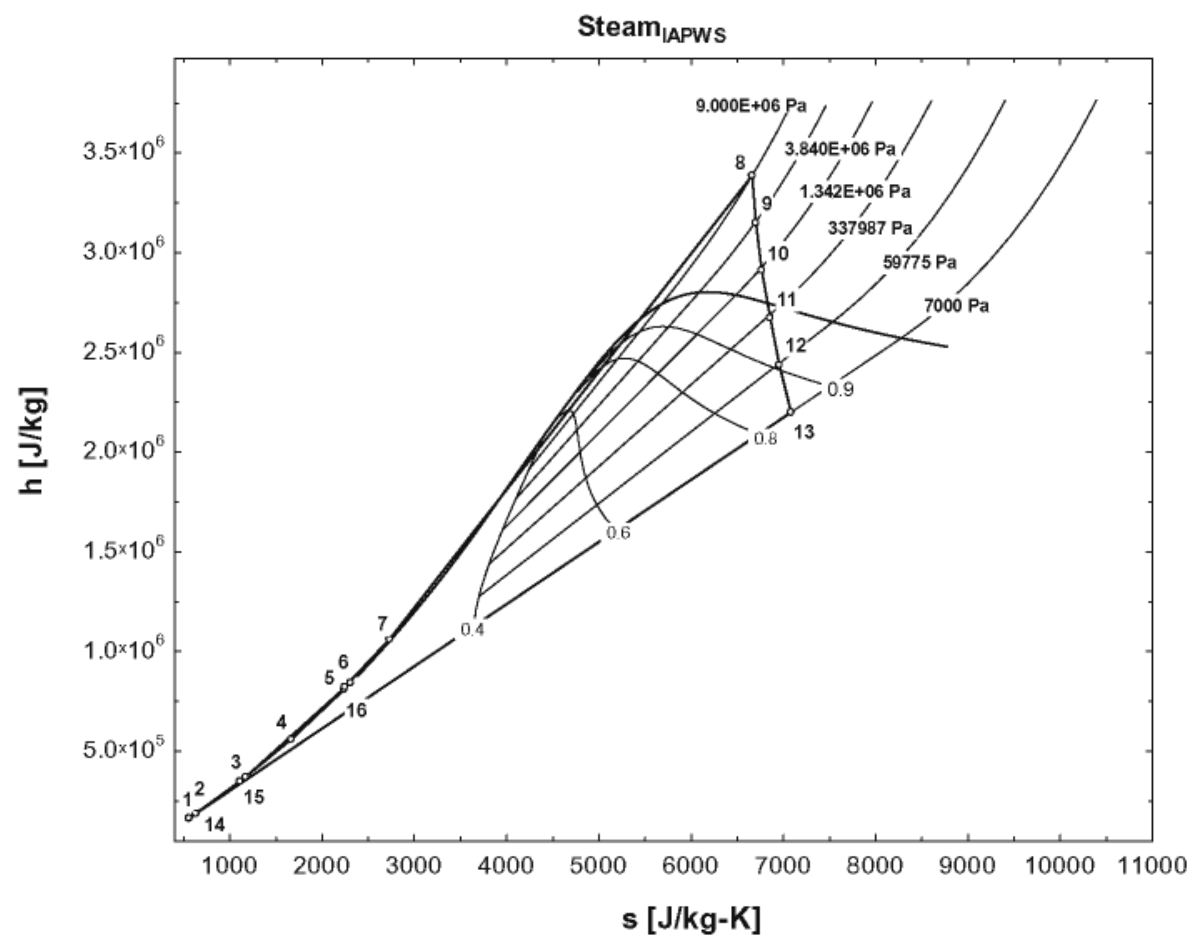

Fig. 3. Mollier diagram for the 50 MWe Rankine cycle considered.

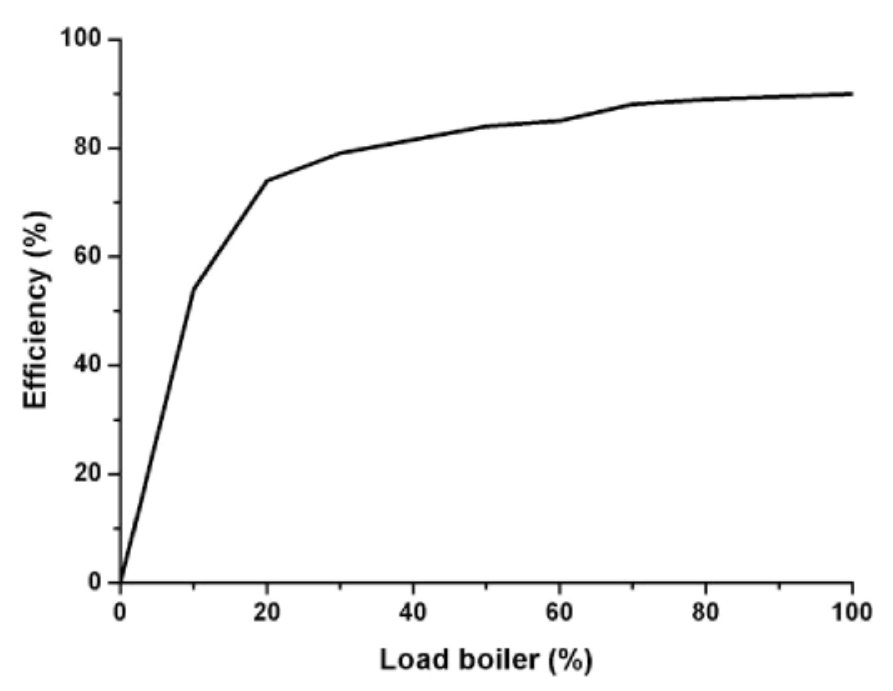

Fig. 4. Natural gas-boiler efficiency as a function of the feedwater load.

an auxiliary fossil-fired boiler is considered, the number of operation hours at nominal conditions will decrease. If only thermal storage is considered, there will be non-insolation intervals in which the Rankine cycle would have to work at part load conditions, owing to the storage system inertia. It is expected that the auxiliary boiler considered, a natural gas-fired boiler, can face up to these insolation fluctuations, smoothing out insolation changes for steadying cycle operation. Nominal thermal power in the natural gas-boiler has been set to $120.4 \mathrm{MWth}$. Actually, this parameter is a design parameter to be optimized because the boiler inversion depends on its nominal power. Never- theless, it has been considered a constant value for all the cases, because the natural gas consumption cost is much greater than the boiler inversion cost. Fig. 4 shows the boiler efficiency during part load conditions (Ganapathy, 1994). Efficiency is almost constant in a wide boiler operation range. When load decreases below $25 \%$, efficiency sharply decreases.

\section{Collector field size and performance as a function of the solar multiple}

It has been said in the previous section that, once the solar multiple and the thermal parameters of the power cycle have been set, the steam mass flow and the thermal power produced in the solar field are fixed. When solar multiple increases, the solar thermal power at nominal conditions also becomes greater. This increasing power is supplied adding parallel loops in the solar field, in such a way that the solar field design always meets the following symmetry requirement: the number of collector loops must be a multiple of four. In practice, each solar multiple tenth means four more loops added in the solar field, as it was showed in Table 1. All the new loops added are exactly the same to the previous ones, that is, dimensions of every section (diameters, length) and optical properties remain constant.

Fig. 5 shows the thermal power produced in the solar field for different direct normal irradiation values. Thermal power approximately follows a linear variation, so a linear regression has been calculated, in order to characterize the 


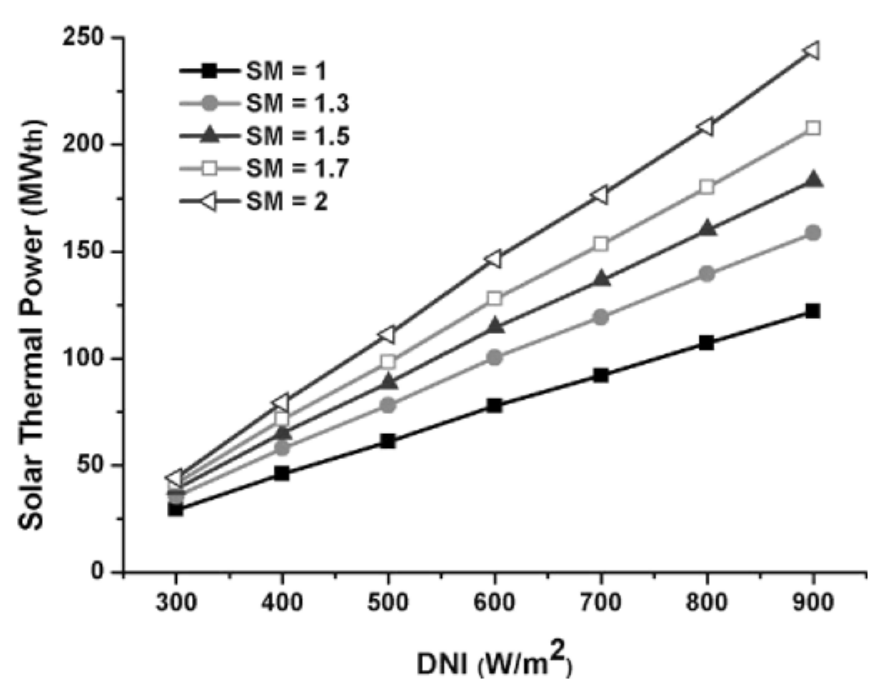

Fig. 5. Solar thermal power as a function of the direct normal irradiation, for different solar multiples.

Table 4

Thermal power produced in the DSG solar field for different solar multiples.

\begin{tabular}{ll}
\hline Thermal power for different solar multiples \\
\hline Solar multiple & Thermal power \\
\hline $\mathrm{SM}=1$ & Thermal power $(\mathrm{MWth})=0.1542^{*} \mathrm{DNI}\left(\mathrm{W} / \mathrm{m}^{2}\right)-15.97$ \\
$\mathrm{SM}=1.1$ & Thermal power $(\mathrm{MWth})=0.1708^{*} \mathrm{DNI}\left(\mathrm{W} / \mathrm{m}^{2}\right)-18.442$ \\
$\mathrm{SM}=1.2$ & Thermal power $(\mathrm{MWth})=0.1876^{*} \mathrm{DNI}\left(\mathrm{W} / \mathrm{m}^{2}\right)-21.201$ \\
$\mathrm{SM}=1.3$ & Thermal power $(\mathrm{MWth})=0.2047^{*} \mathrm{DNI}\left(\mathrm{W} / \mathrm{m}^{2}\right)-24.255$ \\
$\mathrm{SM}=1.4$ & Thermal power $(\mathrm{MWth})=0.222^{*} \mathrm{DNI}\left(\mathrm{W} / \mathrm{m}^{2}\right)-27.588$ \\
$\mathrm{SM}=1.5$ & Thermal power $(\mathrm{MWth})=0.2395^{*} \mathrm{DNI}\left(\mathrm{W} / \mathrm{m}^{2}\right)-31.211$ \\
$\mathrm{SM}=1.6$ & Thermal power $(\mathrm{MWth})=0.2571^{*} \mathrm{DNI}\left(\mathrm{W} / \mathrm{m}^{2}\right)-35.086$ \\
$\mathrm{SM}=1.7$ & Thermal power $(\mathrm{MWth})=0.275^{*} \mathrm{DNI}\left(\mathrm{W} / \mathrm{m}^{2}\right)-39.261$ \\
$\mathrm{SM}=1.8$ & Thermal power $(\mathrm{MWth})=0.2931^{*} \mathrm{DNI}\left(\mathrm{W} / \mathrm{m}^{2}\right)-43.707$ \\
$\mathrm{SM}=1.9$ & Thermal power $(\mathrm{MWth})=0.3113^{*} \mathrm{DNI}\left(\mathrm{W} / \mathrm{m}^{2}\right)-48.403$ \\
$\mathrm{SM}=2$ & Thermal power $(\mathrm{MWth})=0.3298^{*} \mathrm{DNI}\left(\mathrm{W} / \mathrm{m}^{2}\right)-53.427$ \\
\end{tabular}

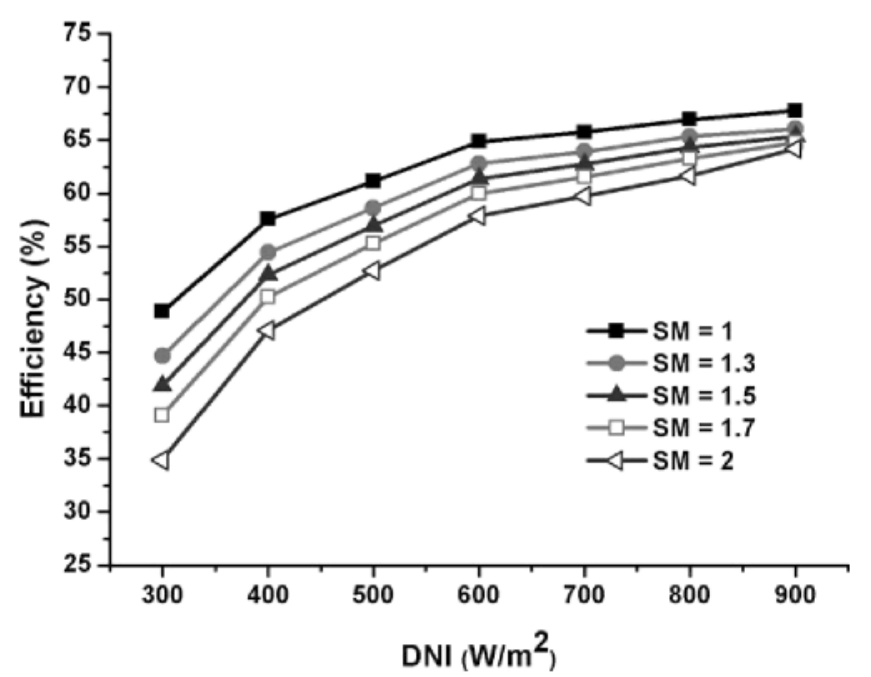

Fig. 6. Solar field efficiency at design-point, as a function of the direct normal irradiation, for different solar multiples.

solar field part load behaviour. Linear functions are shown in Table 4.

As the solar multiple increases, the header pipes length becomes greater, as well as the pressure drop and heat loss associated to the piping system. As a consequence, the steam outlet temperature from a collector loop must be slightly greater and, because the superheating section length remains constant, the steam mass flow at the outlet of the collector loop must be slightly lower. These changes in the working conditions cause the collector loop and the overall solar field efficiencies to decrease, as it can be seen in Fig. 6. This effect is more pronounced at partial load conditions (for beam solar irradiance values below $900 \mathrm{~W} / \mathrm{m}^{2}$ ) because the steam mass flow produced is smaller but the heat loss surface in the piping system is the same (Figs. 7-10).

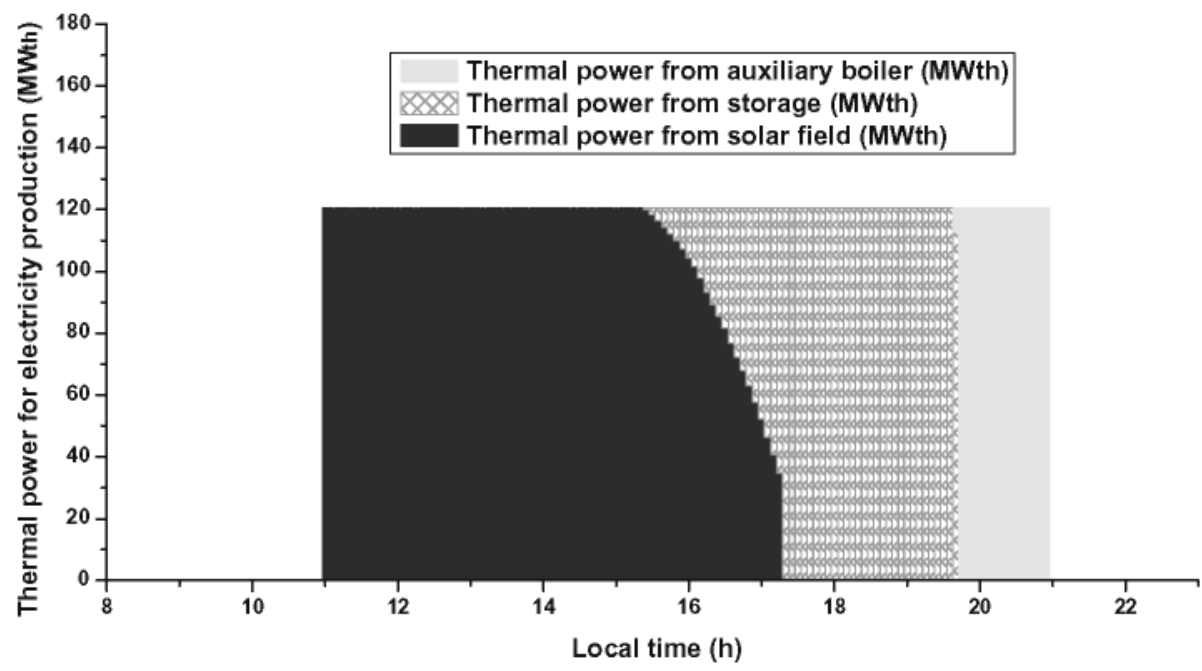

Fig. 7. Operational strategy for a clear day, winter (January 22nd). 

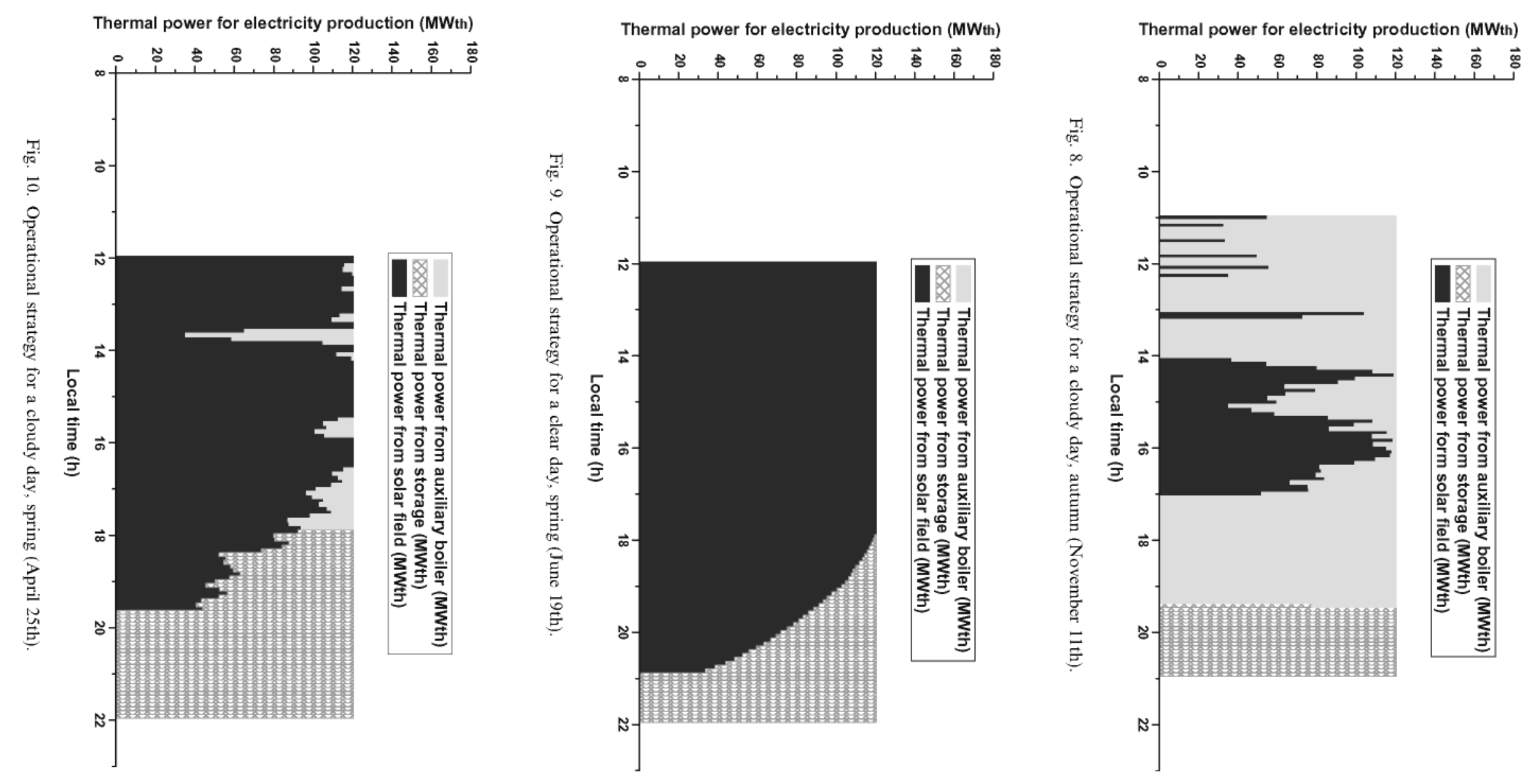


\section{Electricity grid coupling and annual performance}

For all the solar multiples considered, the yearly electricity production has been calculated. The annual plant performance has been simulated on the basis of a reference meteorological year at Plataforma Solar de Almería (PSA) site. Variability of beam solar radiation is presented in five-minutes interval data, so next calculations are based on this working time interval.

In order to simplify calculations, two type-days (a clear day and a cloudy day) have been chosen from every month. Days selected from reference year are listed in Table 5.

Annual results have been carried out taking into account the monthly percentage of clear, cloudy and overcast days in Almería site, for year 2007. This information has been provided by the Spanish Meteorological Institute (Agencia Estatal de Meteorología, 2007) and it is shown in Table 6.

For an operation strategy, both the daily solar plant operation period and the daily electricity production period must be taken into account. The operation hours refers to the time span in which the parabolic trough collectors are focused and, as a result, there is a useful heat gain from the solar field. For the case considered, the solar collectors produce thermal power for direct normal irradiation values above $300 \mathrm{~W} / \mathrm{m}^{2}$. The production hours refers to the period in which the solar power plant is delivering electricity to the grid. The length of this interval is a key decision from the plant owner partners. For the $50 \mathrm{MWe}$ plant considered,

Table 5

Typical days selected from a reference year in Almería, Spain (Source: Plataforma Solar de Almería, 2008. http://www.psa.es/).

\begin{tabular}{lll}
\hline Days from a typical meteorological year & \\
\hline Date & Type of day & Number of day \\
\hline January 4th & Cloudy day, winter & 4 \\
January 22nd & Clear day, winter & 22 \\
February 17th & Clear day, winter & 48 \\
February 27th & Cloudy day, winter & 58 \\
March 7th & Cloudy day, winter & 66 \\
March 11th & Clear day, winter & 70 \\
April 10th & Clear day, spring & 100 \\
April 25th & Cloudy day, spring & 115 \\
May 10th & Cloudy day, spring & 130 \\
May 17th & Clear day, spring & 137 \\
June 16th & Cloudy day, spring & 167 \\
June 19th & Clear day, spring & 170 \\
July 21st & Clear day, summer & 202 \\
July 31st & Cloudy day, summer & 212 \\
August 26th & Clear day, summer & 238 \\
August 30th & Cloudy day, summer & 242 \\
September 13th & Clear day, summer & 256 \\
September 28th & Cloudy day, autumn & 271 \\
October 17th & Cloudy day, autumn & 290 \\
October 29th & Clear day, autumn & 302 \\
November 11th & Cloudy day, autumn & 315 \\
November 26th & Clear day, autumn & 330 \\
December 4th & Clear day, autumn & 338 \\
December 10th & Cloudy day, autumn & 344 \\
\hline & & \\
\hline
\end{tabular}

Table 6

Monthly percentage of clear, cloudy and overcast days in Almería, Spain (Source: Agencia Estatal de Meteorología 2007, http://www.aemet.es/).

Monthly percentage of clear, cloudy and overcast days (2007 data, Almería)

\begin{tabular}{lcll}
\hline Month & Clear days & Cloudy days & Overcast days \\
\hline January & 9 & 19 & 3 \\
February & 3 & 23 & 2 \\
March & 7 & 20 & 4 \\
April & 3 & 20 & 7 \\
May & 9 & 20 & 2 \\
June & 12 & 17 & 1 \\
July & 23 & 8 & 0 \\
August & 13 & 18 & 0 \\
September & 9 & 19 & 2 \\
October & 4 & 24 & 3 \\
November & 9 & 20 & 1 \\
December & 9 & 21 & 1 \\
\hline
\end{tabular}

it has been chosen a ten hours long production period, with different limits in winter schedule (from 11:00 a.m. to 21:00 p.m., local time), and summer schedule (from 12:00 a.m. to 22:00 p.m., local time). Limits have been set in that way because, according to the Spanish electricity feed-in law, these hours are considered an on-peak demand period and the electricity price is affected by a tariff-based incentive.

The operation strategy adopted determines the way in which this electricity is produced. For the particular case presented in this work, this strategy is different for a clear or a cloudy day. For both cases, before the power plant is coupled to the grid, the solar thermal power produced is stored in the system specifically designed to that purpose. While the plant is coupled to the grid, the solar thermal power is used to electricity production; if some power exceeds the nominal power block requirements, this surplus is sent to the thermal storage for later utilization. These operations are common to a clear and a cloudy day. Differences are presented below. When the thermal power supplied by the solar field is not enough to produce $50 \mathrm{MWe}$ in the Rankine cycle, it is necessary to difference between a sudden non-insolation time interval or a conventional variation pattern of direct normal irradiation in a clear day. In this last case (clear day strategy), the remaining thermal power necessary to nominal requirements is provided from the thermal storage, until the solar field can supply nominal power (sunrise) or until the end of the electricity production daily period (sunset). If total discharge is produced before the end of the production period, the gasfired boiler, in parallel to the thermal storage and the solar field, starts to work. If the lack of solar thermal power is produced by some temporary non-insolation conditions (cloudy day strategy), the remaining power to cover nominal requirements, is produced by the auxiliary gas-fired boiler. All the stored energy is used at the end of the production period in order to minimize the turn on / off in the systems. Graphics from 7 to 10 represent the different operational strategies for a clear/cloudy day, and for win- 
ter/summer, in case of considering a solar multiple equal to $1(\mathrm{SM}=1)$.

The average daily efficiency, the thermal storage size and the natural gas consumption are different depending on the operation strategy. Yearly electricity production, annual efficiency and annual natural gas consumption have been calculated, as a weight average taking into account the monthly percentage of clear, cloudy and overcast days. Data for some different solar multiples are showed in Table 7. As the solar multiple increases, the global efficiency decreases, because most electricity is produced by the solar field, with efficiencies lower than those obtained with a fossil-fired boiler. In return, natural gas consumption is lower for higher solar multiples.

In the same way, thermal storage capacity is a function of the solar field size adopted in each case. As it can be observed in the last two columns of Table 7, thermal storage capacity is greater for higher solar multiples because the solar thermal energy surplus that can be used during non-insolation periods, is greater.

\section{Economic analysis}

In previous section, a detailed annual performance analysis of the overall DSG power plant has been performed using meteorological data for a typical year in Almería. Based on these results, the levelized cost of electricity (LEC) has been determined for all the solar multiples considered. The LEC of the different DSG plant configuration analyzed has been calculated according to Eq. (1):

$\mathrm{LEC}=\frac{f c r \cdot C_{\text {invest }}+C_{\text {O\&M }}+C_{\text {fuel }}}{E_{\text {net }}}$

using the annuity factor:

$f_{c r}=\frac{k_{d} \cdot\left(1+k_{d}\right)^{n}}{\left(1+k_{d}\right)^{n}-1}+k_{\text {insurance }}=9.88 \%$

where $k_{d}$ is the real debt interest $=8 \% ; k_{\text {insurance }}$, annual insurance rate $=1 \%$;, depreciation period in years $=$ 30 years; $C_{\text {invest }}$, total investment of the plant; $C_{O \& M}$, annual operation and maintenance costs; and $E_{n e t}$, annual net electricity.

In Table 8, the cost input data for the economic analysis are summarized. Data for investment, operation and maintenance and financial parameters are taken from (Pitz-Paal et al., 2007), where a 50 MWe DSG solar power plant is analyzed. Neither storage nor fossil hybridization is consid-

Table 8

Cost data used for the economic evaluation of the DSG Solar Power Plant.

Cost data used for the economic evaluation of the DSG solar power plant Investment

Specific investment cost for solar field $\left(€ / \mathrm{m}^{2}\right)$ 190

Specific investment cost for power block $(€ / \mathrm{kWe}) \quad 700$

Specific land cost $\left(€ / \mathrm{m}^{2}\right)$

Surcharge for construction, engineering and contingencies 20 $(\%)$

Operation and maintenance

Labor cost per employee and year $(€ / \mathrm{a})$

Number of persons for plant operation

Number of persons for field maintenance

O\&M equipment cost percentage of investment per year $(\%)$

Financial parameters

Annual insurance cost (\%/year)

Lifetime (years)

Debt interest rate $(\%)$

30

$8.00 \%$

Thermal storage

Specific investment cost for thermal storage $(€ / \mathrm{kWhth})$

Fuel cost

Fuel type

Natural Gas HHV $\left(\mathrm{MJ} / \mathrm{m}^{3}\right)$

Natural Gas LHV $\left(\mathrm{MJ} / \mathrm{m}^{3}\right)$

Natural gas price ${ }^{*}(\mathrm{c} \in / \mathrm{kWh})$

Natural gas price $\left(c \in / \mathrm{m}^{3}\right)$

48000
30
10
$(\mathrm{SM}=1)^{* *}$

$1 \%$

00

" Spanish Natural Gas Prices (BOE 2007/20554, http://www.mityc.es/ Gas/Seccion/Precios/).

"* People for field maintenance is increasing in one person each tenth solar multiple increase.

ered in that study, so necessary data to complete this analysis have been taken from other sources. Thermal storage cost estimate has been set according to (Kelly, 2005). For this particular calculation, a specific cost of $31.6 \mathrm{E} / \mathrm{kWhth}$ has been adopted. Natural gas price has been taken form Spanish tariff law.

Calculation results are presented in Table 9, as a function of the solar multiple, which is the determining parameter in solar field configuration for this particular study.

The capacity factor is the same for all the solar multiples because the operation period in which the plant is delivering electricity to the grid remains constant in all the cases considered. Investment cost increases as solar multiple increases because the collector field area and thermal storage size increases. The same variation is observed in the

Table 7

Annual performance parameters and size of thermal storage as function of the solar multiple.

\begin{tabular}{|c|c|c|c|c|c|}
\hline $\begin{array}{l}\text { Solar } \\
\text { multiple }\end{array}$ & $\begin{array}{l}\text { Annual } \\
\text { efficiency }(\%)\end{array}$ & $\begin{array}{l}\text { Annual gas } \\
\text { consumption }\left(\mathrm{m}^{3}\right)\end{array}$ & $\begin{array}{l}\text { Annual fossil fuel percentage in } \\
\text { electricity production }(\%)\end{array}$ & $\begin{array}{l}\text { Size of thermal storage } \\
\text { (equivalent hours) }\end{array}$ & $\begin{array}{l}\text { Size of thermal storage } \\
\text { (MWhth) }\end{array}$ \\
\hline $\mathrm{SM}=1$ & 26.98 & 43099.75 & 29.2 & 3.4 & 409.36 \\
\hline $\mathrm{SM}=1.3$ & 25.64 & 28477.64 & 19.43 & 4 & 481.6 \\
\hline $\mathrm{SM}=1.5$ & 24.77 & 22092.94 & 15.19 & 4.3 & 517.72 \\
\hline $\mathrm{SM}=1.7$ & 23.93 & 17121.03 & 11.77 & 4.7 & 565.88 \\
\hline $\mathrm{SM}=2$ & 22.92 & 12548.67 & 8.65 & 4.8 & 577.92 \\
\hline
\end{tabular}


Economic results for the $50 \mathrm{MW}_{\mathrm{e}} \mathrm{DSG}$ power plant, as a function of the solar multiple.

\begin{tabular}{|c|c|c|c|c|c|}
\hline & $\mathrm{SM}=1$ & $\mathrm{SM}=1.3$ & $\mathrm{SM}=1.5$ & $\mathrm{SM}=1.7$ & $\mathrm{SM}=2$ \\
\hline Collector area $\left(\mathrm{m}^{2}\right)$ & 199874.30 & 266499.07 & 310915.58 & 355332.10 & 421956.86 \\
\hline Nominal Power $\left(\mathrm{MW}_{\mathrm{e}}\right)$ & 50 & 50 & 50 & 50 & 50 \\
\hline Total solar thermal power plant area $\left(\mathrm{km}^{2}\right)$ & 0.71 & 0.95 & 1.11 & 1.26 & 1.50 \\
\hline Investment cost (Mio.€) & 104.80 & 123.30 & 135.18 & 147.51 & 163.73 \\
\hline Annual O\&M cost (Mio.€) & 2.97 & 3.30 & 3.51 & 3.73 & 4.04 \\
\hline Annual fuel consumption $\left(\mathrm{m}^{3}\right)$ & 43099.75 & 28477.64 & 22092.94 & 17121.03 & 12548.67 \\
\hline Annual fuel Cost (Mio.€) & 0.0106 & 0.0070 & 0.0055 & 0.0042 & 0.0031 \\
\hline Capacity factor $(\%)$ & 41.67 & 41.67 & 41.67 & 41.67 & 41.67 \\
\hline LEC $(€ /$ MWhe $)$ & 78.68 & 84.87 & 92.47 & 100.35 & 110.80 \\
\hline LEC (relative value, \%) & 100.00 & 107.88 & 117.53 & 127.54 & 140.83 \\
\hline
\end{tabular}

annual operation and maintenance cost, owing to the increasing number of persons for field maintenance and equipment repair costs for greater collector areas. Nevertheless, annual gas consumption decreases for increasing solar multiples because of the increasing solar thermal power percentage in yearly electricity production.

To finish the economic study, it can be observed that the levelized electricity cost increases as solar multiple increases, because the investment cost is the most important factor in the calculation of this parameter. The absolute values of the LEC depend largely on the parameters selected for the economic model so, in the last row of Table 9 , relative values are presented, and the least cost option is set to $100 \%$.

\section{Conclusions}

A detailed system analysis has been performed, assessing the influence of the solar multiple on the annual performance of direct steam generation solar thermal power plants. Simulations presented in this work are based on a reference $50 \mathrm{MWe}$ DSG plant, with thermal storage and auxiliary natural gas-boiler. Although thermal storage technology for DSG plants is not available in a commercial scale, both systems must be considered if a scheduled load operation mode is adopted.

As a previous step to the annual performance, the daily operation strategy for every DSG plant configuration, characterized by the solar multiple, has been obtained for two type-days: a clear day and a cloudy day. In order to estimate the yearly parameters for every solar multiple considered, a weight average has been calculated, taken into account the monthly percentage of clear, cloudy and overcast days. This method of assessing the annual plant performance, using only one clear day and one cloudy day in every month can be applied for sites where only limited meteorological data are available.

Economic analysis has been carried out, on the basis of annual characterization for every configuration. LEC values have been obtained for a specific economic scenario. For this reason, the most relevant information is provided by the comparative study between different configurations. It can be observed that levelized cost of electricity is greater as the solar multiple of the power plant increases, mainly owing to the great investment cost in the solar field. Nevertheless, it is important to point out that the annual fuel consumption is reduced for a solar multiple increase because the thermal power fractions from the solar field and the storage become greater. This reduction is important if annual fossil fuel percentage for electricity production is limited by the national electricity feed-in law, there will be a lower limit in the solar multiple selection range.

In summary, this paper shows the great influence of the solar multiple in daily operation, annual performance, and economy of a DSG parabolic trough plant.

\section{References}

Agencia Estatal de Meteorología, 2007. http://www.aemet.es/.

Benz, N. et al., 2008. Advances in receiver technology for parabolic troughs. In: Proceedings of 14th International SolarPACES Symposium on Solar Thermal Concentrating Technologies, Las Vegas, USA.

Birnbaum, J. et al, 2008. A direct steam generation solar thermal power plant with integrated thermal storage. In: Proceedings of 14th International SolarPACES Symposium on Solar Thermal Concentrating Technologies, Las Vegas, USA.

Eck, M. et al., 2008. Direct steam generation in parabolic troughs at $500{ }^{\circ} \mathrm{C}$ - A German-Spanish project targeted on component development and system design. In: Proceedings of 14th International SolarPACES Symposium on Solar Thermal Concentrating Technologies, Las Vegas, USA.

Ganapathy, V., 1994. Understand boiler performance characteristics. Hydrocarbon Processing 73 (8), 131-136.

Kelly, B., 2005. Nexant Parabolic Trough Solar Power Plant Systems Analysis. Task 1: Preferred Plant Size. Report No. NREL/SR-55040162, NREL, Colorado.

Kelly, B., Kearney, D., 2006. Parabolic Trough Solar System Piping Model. Report No. NREL/SR-550-40165, NREL, Colorado.

Kostyuk, A., Frolov, V., 1988. Steam and Gas Turbines. Mir, Moscow, pp. 13-33/136-161.

Montes, M.J. et al., 2008. Thermofluidynamic model and comparative analysis of parabolic trough collectors using oil, water/steam or molten salt as heat transfer fluids. In: Proceedings of 14th International SolarPACES Symposium on Solar Thermal Concentrating Technologies, Las Vegas, USA.

Pitz-Paal, R. et al., 2007. Development steps for parabolic trough solar power technologies with maximum impact on cost reduction. Journal of Solar Energy Engineering 129 (4), 371-377.

Plataforma Solar de Almería, 2008. http://www.psa.es/. 
Price, H. et al., 2002. Advances in parabolic trough solar power technology. ASME Journal of Solar Energy Engineering 124 (2), 109-125.

Winter, C.J. et al., 1990. Solar Power Plants: Fundamentals, Technology, Systems, Economics. Springer-Verlag, Berlin, pp. 199-214.

Zarza, E., 2007. Personal communication. Plataforma Solar de Almería (PSA, 2007). http://www.psa.es.
Zarza, E. et al., 2006. INDITEP: the first pre-commercial DSG solar power plant. Solar Energy 80 (10), 1270-1276.

Zarza, E. et al., 2008. Almería GDV: the first solar power plant with direct stem generation. In: Proceedings of 14th International SolarPACES Symposium on Solar Thermal Concentrating Technologies, Las Vegas, USA. 